\title{
Weblogs for Developing English Academic Reading Skills of Pre-Master students
}

\author{
Heba M. Abdullah \\ TEFL Lecturer, Faculty of Graduate Studies for Education, Cairo University \\ (email.heba_mustafa@cu.edu.eg)
}

\begin{abstract}
The study examines the effect of the use of weblogs on developing academic reading skills of pre-master students. The sample of the study consisted of one hundred and forty $(n=140)$ pre-Master students enrolled in the English for Academic Purposes (EAP) course, Faculty of Graduate Studies for Education, Cairo University. The study used the quasi-experimental design. Hence, the sample of the study $(n=140)$ has been assigned to a control group $(n=70)$ and an experimental group $(n=70)$. Both groups were taught by the researcher simultaneously for a period of three successive months, i.e. a semester. For the purpose of data collection, a pre-post academic reading test was designed and administered to both groups before and after the treatment. Results of the study provided an evidence on the positive effect of using the weblog on developing academic reading skills of pre-master students enrolled in the EAP course $(\mathrm{n} 2=.987)$. Students' progress can be mainly attributed to the well-established elearning community provoked by the weblog. The study was limited to the use of one type of weblogs; namely tutor. More research is needed to investigate the implementation of other weblogs types in other EAP contexts.
\end{abstract}

Keywords

Weblog; Academic Reading Skills; English for Academic Purposes; Pre-Master Students 


\section{Weblogs for Developing English Academic Reading Skills of Pre-Master students}

Recently, web 2.0 technologies provide educators and scholars with new horizons in learning and teaching. With the remarkable interactivity of modern digital tools, new opportunities in foreign language learning came to exist. In the context of English as a foreign language (EFL) instruction, weblog as an instructional tool has gained an increasing attention.

Terminologically speaking, 'weblog' is a compound word of 'web' and 'log'. As the term suggests, a 'weblog' is a publication on the worldwide web in which contributions are demonstrated chronologically, much like a diary or journal (Goldstein, 2009).

\section{Characteristics of weblogs}

Weblogs are characterized by numerous features that distinguish them from other web-based asynchronous communication tools and enable them to be recognized as a unique learning platform (Featro and Digeorio, 2016). Among these features, the following are mentioned :

- Theme-based: weblogs are themed around certain topics where posts are to be published in relevance. Each post contains a subject title and a message serves as a documentation. Readers of a weblog have an opportunity to respond to a blog post through a comment or a link. These comments constitute a thread as many as readers can comment on a single post. Accordingly, a discussion is to be provoked among the readers with diverse viewpoints around a certain topic. weblogs can be classified according to themes into five main types, namely; personal, community, education, and knowledge (Ayers, 2011).

- Community builder: weblogs are managed by administrators who are responsible for publishing the blog content, moderating readers' comments, and setting common grounds for participation. This allows a trusting relationship among readers and administrators to take place. Readers also address each other responding, sharing, supporting or even opposing views. Hence, social identities for weblog users are raised naturally and independently paving the way for the establishment of a learning community (Thiyagu, 2013).

- Resourceful: weblogs auto-archive older posts in a chronological order. That is, the newest posts are to be placed on the top whereas 


\section{Dr. Heba M. Abdullah}

the oldest are to be provided below (Lerma, 2013). In addition, readers are allowed not only to come across posts but also to browse other linked weblogs that share the same interest (Wan et al., 2012). Moreover, weblogs enable contributors to integrate varied formats, such as; images, audio files, texts and videos, and links to other Webpages. Accordingly, a weblog can serve as a starting point for finding unlimited relevant information resources (Smith, 2009).

- Customizable: weblogging free platforms offer an unlimited number of pre-existing templates, including a variety of graphical layouts, and color schemes; such as Edu-blogs, Blogger, and Wordpress. Accordingly, weblogs provide a feeling of personalization for administrators and readers without any required sophisticated technical experiences (Bartholomew et al., 2012; Kelsey, 2010).

\section{Weblogs and language instruction}

The use of weblogs is mainly rooted in the social constructive learning theory where interaction, authenticity, social presence, and negotiation are recognized as factors to determine successful learning (Coppens et al., 2013). In addition, the cognitive development of learner is much influenced by community-based learning that is developed through weblogs. Sun (2009) asserts that "weblogs can constitute a dynamic forum that fosters extensive practice, learning motivation, authorship, and development of learning strategies...The worldwide audience enables students to interact with and have their work viewed by others outside classroom" ( p. 88).

Weblogging has been reported to bring about varied impacts on language learning. Aydin (2014) has reported positive effects of weblogs on enhancing EFL learners' cultural awareness, communication, basic skills, motivation and autonomous learning. Other studies have pointed to the valuable role played by weblogs in enhancing discrete EFL skills. Regarding the writing skill, several attempts have been made to examine the use of weblogging in teaching writing courses (Alvarez and Bassa, 2013;Asoodar ,2014; Ching-Huang et. al., 2011; Cox, 2012; Dewi, 2013; Glicker, 2010 ;Grami,2012; Guo, 2013; Huei et al., 2013; Hu and Wu, 2012; Jayne, 2013; Kitchakarn, 2012; Kitchakarn, 2014; Lacina and Griffith, 2012; Lin et al., 2011; Lin, 2014; Peterson, 2009; Peterson, 2012; Sun, 2010, Termsinsuk, 2015; Wu, 2015). Together, these studies provide important insights into the positive impact of using weblogs on developing EFL learners' writing performances,sub-skills and abilities 
within university education including English for Academic Purposes ( EAP )learning contexts.

Furthermore, a considerable amount of studies has paid particular attention to the impact of weblogs on oral communication skills including speaking and listening (Davis and McGrail, 2009; Hung, 2011; Suryani et al., 2012). Drawing on their results, the role of weblogs in enhancing communication skills is emphasized. Other studies questioned the usefulness of weblogs in EFL literacy instruction, i.e, reading and writing (Alvarez, 2012; Ananyeva, 2014; Elbelzai, 2015; Hutchison and Wang, 2012; Morgan, 2015; Stover et al., 2014). These studies provided evidence that weblogs usage is highly suggested in EFL literacy instruction.

In addition to language skills, a number of studies investigated the impact of weblogs implementation on elements of EFL acquisition process, such as; learners' perceptions (Alaboudi, 2014; Aljumah, 2012; Ruggiero, 2016; Sadikin and Saleh, 2016; Wan and Tan, 201; Wu and L.Wu, 2011), reflection (Hajizadeh, 2011), awareness (Johnson, 2012), creativity (Johnson, 2010), motivation (Krishnan, 2010), reading habits (Makhadmeh, 2011), reading engagement (Park, 2013), reading and writing habits (Quadir and Chen, 2015), anxiety (Sandlin, 2013) and higher order thinking skills (Zawilinski, 2009).

It is noteworthy that the relationship between the type of employed weblog and functions that they serve in the EFL learning process has been highlighted. However, weblogs have four main types in relation to EFL instruction (Moon and Lim, 2013; Supyan, 2011, Zarei and Supyan, 2016; Thiyagu, 2013) as follows.

\section{(A) Tutor Weblog}

It is a weblog that is administered and published by the instructor. It can be used as a classroom management tool where students' class requirement, handouts, notes, assignments, objective or course syllabus are published and frequently updated. In addition, recommended links for other weblogs or resources are provided for students. In the same time, posts are highly relevant to the course material and organization. Hence, tutor weblogs provide students with opportunities for guided discussion where they can exchange information and practice reflection and peer assessment (Alexander and Bach, 2013). Furthermore, posts are chronologically archived offering students with a permanent gateway for 
information. Simultaneously, they enable teachers to monitor students' progress and provide feedback at proper intervals.

\section{(B) Learner weblog}

It is administered and published by the learners themselves. Students can communicate freely with their classmates. They continuously strive to practice self-expression and personal reflection about any topic. Such type of weblogs can be described as an e-portfolio which include all written work provided by a learner within a course. Instructors are not allowed to control or filter weblog posts (Lin, 2015). Hence, learner weblogs provoke a highly interactive discussion among learners to share interests in same learning topics (Alhuwalia and Gupta and Aggarwal, 2011). However, instructors may find difficulty in assessing, grading or even monitoring the learners' progress through such weblogs.

\section{(C) EFL weblog}

It is a weblog designed to provide EFL learners by learning sources. Learners may search the worldwide web to find the preferable EFL weblog. It usually provides authentic learning materials including texts, images, audio files, and videos. In addition, it may enable learners to participate in learning communities with native-like speakers. It extends not only to peers and teachers but also to people beyond the classroom. Usually, EFL weblogs can serve as a rich medium for cultural exchange as well as intercultural awareness.

\section{(C) Class weblog}

It is managed by both the teacher and students on basis of collaboration. It opens the opportunity for students to discuss topics and share thoughts outside the classroom. It can serve as an extra-curricular activity where deep understanding and collaborative processes of knowledge construction are fostered. In addition to topics assigned for homework, learners can share relevant web sources according to their pace, interest, and preferences. Accordingly, a class weblog is thought to provoke a collaborative learning environment where learners have the space to work on a shared group production (Gunduz, 2016; Alvatrez and Bassa, 2013).

To conclude, there seems to be an evidence that weblogs can not only sustain discussion outside a classroom, but also provide learners with possibilities to enhance language learning, acquisition, and skill development. Such possibilities are much related to the utilized weblog type and function. For the present study, a tutor's weblog is used as an 
instructional tool and complement to extend classroom discussions via moving assignments from a static process of knowledge retention into a dynamic process of reflection and reconceptualization. Its integration into the designed EAP course is determined to establish an online learning community and to offer opportunities for students to become knowledge co-constructors and co-users.

\section{English for Academic Purposes (EAP)}

The origins of EAP are dated back to the 1960s, as a branch of the rapidly developed discipline of English language teaching (ELT), namely; English for specific purposes (ESP) (Besahj, 2014). The growth of ESP was mainly influenced by the new linguistic trends and language acquisition theories. Otilia (2015, p. 222) mentions that "ESP focuses on practical aspects derived from needs analysis, genre analysis, and effective communication". That is, ESP is basically directed towards qualifying learners with specific linguistic knowledge and skills closely related to what they have to do, later on, through a medium of English language. In other words, "ESP aims at meeting the very specific needs of a very specific group of learners" (Ramirez, 2015, p. 385).

There are fundamental features that distinguish ESP from General English (GE). Firstly, it is designed to meet specific needs of adult learners either at a specific field of study or in a professional work situation. Secondly, it assumes that learners have basic knowledge of language system, i.e., not beginners. This view is supported by Rahman (2015) who mentioned that

the most important difference between ESP and GE is that the learners and their purposes for learning English. ESP learners are usually adults who already have some acquaintance with English and learn the language so as to communicate a set of professional skills and to perform particular profession-related activities (p.24).

Derived from ESP, EAP courses aim to improve learners' level of English and to "introduce them to the linguistic conventions and academic skills they need for their university study" (Terraschke and Wahid, 2011, p. 174). Such courses are developed with a due attention to language in context rather than isolate grammar and language structure. In addition, EAP syllabuses do not stress all four language skills equally, rather the most needed skills are only emphasized. Accordingly, needs analysis is considered the key stage of EAP that leads to a specific course (Durrant, 2009). In the same vein, Rahman (2015, p. 26) emphasizes the use of three fundamental types of needs analysis, namely; 'target situation 
analysis', 'learning situation analysis', and 'situation analysis'. On his part, Kilmova (2015, p. 634) advocates the utilization of varied tools to determine the needs of language skills in EAP contexts, including; tests, questionnaires, interviews, observation, and consultations. For the purpose of this study, needs analysis is described as "a process of determining EAP learners' needs that encompasses administering a valid questionnaire".

To date, there has been little agreement on the identification of EAP instruction. In a broad sense, Rahman (2015, p. 25) mentions that "EAP refers to any English teaching that relates to academic study needs". This view is supported by Campion (2016) who describes EAP in terms of knowledge, skills, and activities that are most needed in academic contexts. Conversely, Green (2015) argues that EAP is an instructional approach that underpins the use of several instructional strategies to foster the transfer of learning as an ultimate goal. Others (Afshar and Movassagh, 2016; Zhou, 2009) emphasize the primacy of needs analysis for the EAP course which focuses on learners' needs and does not involve a particular kind of teaching material or methodology. Rather, it makes use of varied techniques and activities that serve its objectives (Yigityoglu, 2016). In this study, EAP refers to a "course design that is based on EFL learners' needs related to their further post graduate studies".

\section{EAP Instruction}

Researchers have shown an increased interest in investigating the development of language learning process in general, and language skills in particular within EAP contexts. With regard to the language learning process, a number of researchers have explored varied aspects, including; vocabulary size (Akbarian, 2010 ; Durrant, 2009), teachers' beliefs (Alexander, 2012), students' perceptions (Cai, 2013; Guo, 2012; Khany and Tarlani-Aliabadi, 2016), EAP learners' beliefs (Li and Ruan, 2015), EAP learners' perspectives (Dooey, 2010), EAP teacher's knowledge (Schmitt and Hamp-Lyons, 2015), assessment (Seviour, 2015), EAP learners' experiences (Terraschke and Wahid, 2011), teachers' practices (Wette, 2014).

As for language skills, EAP instruction has received considerable attention. Bankowski (2010) has reported the development of Academic presentation skills in EAP contexts on basis of independent research work. Other studies (Houston, 2014; Storch and Tapper, 2009; Wingate, 2012) have indicated that EAP learners' writing skills can be fostered by integrating more authentic writing practices and genres. EAP learners' 
reading skills have been addressed by some studies (Neculai, 2016; Nergis, 2013; Ro, 2016) exploring specific areas, respectively; meaning making, comprehension, extensive reading. Furthermore, Ward (2009) has presented evidence on the estimated relationship between EAP learners' reading skills and their lexis repertoire. In his study, Wilson (2016) found that EAP learners' critical reading skills can be developed by different ways stating "students' critical dispositions require delicate scaffolding to support their development as critical meaning makers" ( $p$. 256). In the same vein, Esnawy's (2016) study indicated the effective use of Jigsaw technique in enhancing EAP learners' reading skills and research essay writing. Overall, these studies stressed the need for examining the development of language skills, in general, and reading skills within an EAP context as a distinct area of investigation. With respect to the postgraduate studies, Irmawati $(2012$, p. 90) stresses the significance of reading instruction within EAP context stating "academic reading is a difficult subject to be mastered. It is needed because most of books or references are written in English".

\section{EAP and reading instruction}

Taking into consideration that an EAP course is designed for the purpose of using language in a particular domain, needs analysis can be considered as fundamental. Information collected by the process of needs analysis is crucial for formulating goals, identifying learners' target English knowledge and relevant practices. According to Kuzborska (2011), reading instruction within EAP context should be based on a comprehensive needs analysis process that addresses the following areas.

- The types of reading abilities students will have to apply in academic reading, as this information will help teachers formulate specific goals and objectives of reading materials.

- The types of learning target, genres, and topics students will have to read, as this information will facilitate finding relevant input materials.

- The situation in which students need to read in English as well as the assessment of students' current reading abilities in English, as this information will allow teachers to create reading activities appropriate to students' disciplines (p. 224).

Despite the ongoing debate on aspects of academic language proficiency development (Spies, 2011), features of reading instruction in 


\section{Dr. Heba M. Abdullah}

EAP contexts have been explored (Kuteeva, 2011; Lou, 2010; McCollum, 2011; NCUK, 2013; Pluck, 2013; Suh, 2011) as follows:

- Providing EAP learners with authentic, materials that relate them more closely to targeted study contexts.

- Exposing EAP learners to varied models of academic text genres that are typically representative of a context area of specialization.

- Raising EAP learners' awareness of text structure as identified by reading experts.

- Exploring a set of themes or topics that trigger contextualization, relevance, and coherence to the overall learning context.

- Resembling the ways in which EAP learners may read in reality throughout the use of real-life activities whether inside or outside EAP classrooms.

- Raising EAP learners' awareness of rhetorical features in academic writing and citation rules (Mansourizadeh and Ahmad, 2011; Tasildar,2011) which pay an important role in the meaning construction process.

However, debate continues about the best pedagogical practices for the development of EAP learners' reading skills (McGrath et al., 2016; Ro, 2016; Wilson, 2016; Yigiloglu, 2016). In this context, Gimerez and Haywood (2010) simply emphasized only two main concerns stating

One significant aspect of reading in EAP is the vast reading load that students are faced with, and one control role of any EAP teacher is precise to equip students with this, so that, they can navigate their way through the resources available to them (p.336).

Moreover, EAP learners' reading abilities have been analyzed, described and identified in varied ways (Naidu et al., 2013; Taboada and Buehl, 2012; Veenendal et al., 2015). For the purpose of this study, academic reading skills are defined as the active meaning-making processes that entail EAP learners' recognition of prominent features of texts within an area of specialization ( i.e education )and abilities targeted on basis of needs analysis.

Despite the importance of academic reading skills for EAP learners (Esnawy, 2016; Irmawati, 2012; Neculai, 2010; Nergis, 2013; RO, 2016; Ward, 2009, Wilson, 2016), little attention has been paid to their development in respect to their specific needs (Ahmed, 2008; Faidh, 2007; Hafiz, 2008; Al-Husseini, 2014). 


\section{Context of the problem}

Working as an EFL lecturer at Faculty of Graduate Studies for Education, the researcher observed that students enrolled in the preMaster program are weak in English academic reading skills. So, the researcher conducted a pilot study by administering an English academic reading test to a group of thirty-six $(n=36)$ of pre-Master students. Results revealed that $78 \%$ of the students suffer from poor mastery of academic reading skills, which can be ascribed to little attention paid to instructional practices of EAP courses offered to pre-Master students. Moreover, the researcher administered a questionnaire about students' major language academic needs and the most suitable instructional practices, to a group of forty $(n=40)$ students enrolled in pre-Master program 2014-2015, at Faculty of Graduate Studies for Education, Cairo University. ( This questionnaire is shown in Appendix (A) )

Results of the questionnaire indicated the following:

- $95 \%$ of the students enrolled in the EAP course are going to write their Master thesis in the standard Arabic language. Yet, $100 \%$ of the students declared that English language mastery is very important with respect to their further academic studies.

- $70 \%$ of the students stated that their most difficult area in English language learning is speaking. However, 95\% of students choose 'written material' as the most needed type of English resources in their further studies.

- $98 \%$ of the students agreed on the potential benefits of an English course that addresses more specific needs. In addition, 95\% of the students ranked the item 'read academic texts about subject related topics' as the most important task according to their academic needs.

- $89 \%$ preferred learning via 'interactive activities' than individual work. Moreover, $97 \%$ reported their frequent use 'once a day' of webtools for educational purpose.

\section{Statement of the problem}

According, the problem of the study can be stated as follows:

Pre-Master students are weak in English academic reading skills, which may be attributed to instructional practices of the EAP course offered in the pre-Master program. Hence, the study examines the use of 


\section{Dr. Heba M. Abdullah}

weblogs for developing academic reading skills of pre-Master students enrolled in the EAP course.

\section{Questions of the Study}

The major question of the present study is:

What is the effect of using weblogs on developing English academic reading skills of pre-Master students?

The previous question is branched into the following set of sub-questions:

1- What are the EFL needs of pre-Master students enrolled in the EAP course?

2- What is the effect of using weblogs on developing the overall academic reading skill of the pre-Master students enrolled in the EAP course?

3- What is the effect of using weblogs on developing academic reading sub-skills of pre-Master students enrolled in the EAP course?

\section{Hypothesis}

1- There are statistically significant differences between the mean scores of the experimental and the control group students in the postadministration of the academic reading test in favor of the experimental group.

2- There are statistically differences between mean scores of the experimental group students on the pre and post- administrations of the academic reading skill test in favor of the post-administration.

\section{Method}

\section{Participants}

The sample of the study consisted of one hundred and forty $(n=140)$ pre-Master students enrolled in the EAP course, Faculty of Graduate Studies for Education, Cairo University. All participants had not received any previous EAP courses. However, participants' mastery level of general English was low-intermediate based on their scores in the TOFEL test. Participants' age ranged from 25 to 30 years old.

\section{Instruments}

\section{(A) Needs Analysis Questionnaire}

A needs analysis questionnaire was designed to identify Pre-Master students' EFL needs. If consisted of two main sections; (a) Background (b) major and specific language needs. The questionnaire was admitted 
to a panel of three Jury members of EFL specialists for validation (see Appendix (B) for a final version).

\section{(B) Academic Reading Test}

To assess students' mastery of academic reading skills, a test was designed by the researcher. It included eighteen (18) test items with total marks (90). To ensure the test validity, it was administered to three TEFL specialists. Time allotted to the test was determined by calculating the average time taken by a sample of twenty (20) students, who were selected voluntary for test piloting. In addition, the reliability of the test was calculated using Cronbach alpha. It was (0.817), significant at 0.01 level (for final version and test specifications, see appendix (C) )

\section{(C) Weblog Questionnaire}

A questionnaire was designed to gather feedback and students' comments on the weblog as an instructional tool at the end of the EAP course. It includes five (5) open-ended questions where students freely reflect on their weblogging learning experiences (for the final version, see appendix (D)).

\section{Procedures}

A needs' analysis questionnaire was administered to a group of one hundred and forty (140) of EAP learners enrolled in the pre-Master program, Faculty of studies for Education, Cairo University. It aimed at identifying the most needed academic EFL skills as well as instructional practices in relation to their further post graduate studies. Results obtained from the questionnaire were statistically treated (see appendix (E)). Based on these results, the weblog's design and content were identified. (For weblog content description, see appendix (F)).

The implementation of the weblog started on the $4^{\text {th of }}$ October and ended up on the $19^{\text {thof }}$ December, 2014. The sample of the study $(n=140)$ has been assigned to a control group $(n=70)$ and an experimental group $(n=70)$. Both groups were taught by the researcher simultaneously for a period of three successive months, i.e a semester. The researcher met both groups once weekly in a traditional classroom setting for total duration 28 hours. The control group was taught in the regular instruction, i.e., presentations and limited classroom-discussions, whereas the experimental group students were taught using the weblog as an instructional tool that extended classroom discussions and provoked a vivid online learning community. At the end of the EAP course, the 


\section{Dr. Heba M. Abdullah}

academic reading test was re-administered to both groups. (For EAP course description see appendix $(\mathrm{G})$ ).

\section{Results}

All data were treated statistically using the package for social science (SPSS), namely; independent t-test, paired sample t-test, and Eta square. Prior to conducting the experiment, it was essential to investigate if there were any statistically significant differences among participations in respect to the academic reading skills. Hence, results of the preadministration of the academic reading test were analyzed using independent samples t-test.

Table 1. T-Test Results of Pre-Administration of the Academic Reading

Test Comparing the Control and Experimental Groups Mean Scores in the

Overall Academic Reading Skill.

\begin{tabular}{|l|l|l|l|l|l|l|}
\hline Group & Mean & N & Std. & DF & T & Sig. \\
\cline { 1 - 5 } Control & 17.1429 & 70 & 8.32194 & 138 & 2.226 & $\begin{array}{l}.068 \\
\text { Not } \\
\text { Sig. }\end{array}$ \\
\cline { 1 - 3 } Experimental & 16.2143 & 70 & 7.80486 & & & . \\
\hline
\end{tabular}

As indicated in table (1), there were no statistically significant differences between the mean scores of the experimental and control groups on the pre-administration of the academic reading test, i.e., the estimated t-value was (2.226) which is not significant at 0.01 level. Hence, it could be said that both groups were homogenous in terms of the level of the students' mastery of academic reading skills before conducting the experiment.

In respect to the first hypothesis, mean scores of the experimental and control groups' students on the post-administration of the academic reading test were compared using independent t-test as shown in table (2)

Table 2. T-Test Results of Post-Administration of the Academic Reading Test Comparing the Control and Experimental Groups Mean Scores in the Overall Academic Reading Skill.

\begin{tabular}{|l|c|c|c|c|c|c|c|}
\hline \multicolumn{1}{|c|}{ Group } & Mean & $\mathbf{N}$ & std. & df & t & Sig & Eta \\
\hline Control & 37.1429 & 70 & 10.27066 & 138 & 25.201 & .000 & .907 \\
\cline { 1 - 4 } Experimental & 74.6429 & 70 & 7.03621 & & & & \\
\hline
\end{tabular}


Results showed that there were statistically significant differences at 0.01 level in favor of the experimental group, i.e., estimate t-value is (25.2).

To verify the second hypothesis, paired sample t-test was conducted for comparing mean scores of the experimental group students on the pre- and post-administrations of the academic reading test.

Table 3. t-Test Results of Pre- and Post-Administrations of the Academic Reading Test Comparing Experimental Group students 'Mean Scores.

\begin{tabular}{|c|c|c|c|c|c|c|c|}
\hline \multicolumn{2}{|l|}{ Academic Reading sub-skills } & $\mathbf{N}$ & Mean & S.D & $\mathbf{t}$ & Sig & Eta \\
\hline \multirow{2}{*}{$\begin{array}{l}\text { 1-Differentiate between common } \\
\text { types of sources in the } \\
\text { educational field ( books, } \\
\text { articles...) }\end{array}$} & Pre & 70 & 2.0000 & 2.46718 & \multirow[t]{2}{*}{38.465} & \multirow[t]{2}{*}{0.00} & \multirow[t]{2}{*}{.854} \\
\hline & post & 70 & 17.1429 & 3.13598 & & & \\
\hline \multirow{2}{*}{$\begin{array}{l}\text { 2-Identify the main idea of an } \\
\text { educational text }\end{array}$} & Pre & 70 & 1.5942 & 2.34721 & \multirow[t]{2}{*}{11.662} & \multirow[t]{2}{*}{0.00} & \multirow[t]{2}{*}{.975} \\
\hline & post & 70 & 4.9275 & .60193 & & & \\
\hline \multirow{2}{*}{$\begin{array}{l}\text { 3-Recognize the general } \\
\text { structure of educational essays } \\
\text { (introduction- body....) }\end{array}$} & Pre & 70 & 2.0000 & 2.46718 & \multirow[t]{2}{*}{22.254} & \multirow[t]{2}{*}{0.00} & \multirow[t]{2}{*}{.765} \\
\hline & post & 70 & 8.8571 & 2.11472 & & & \\
\hline \multirow{2}{*}{$\begin{array}{l}\text { 4-Distinguish facts from } \\
\text { assumptions and opinions }\end{array}$} & Pre & 70 & 1.7143 & 2.53750 & \multirow[t]{2}{*}{21.906} & \multirow[t]{2}{*}{0.00} & \multirow[t]{2}{*}{.981} \\
\hline & post & 70 & 9.0000 & 2.01444 & & & \\
\hline \multirow{2}{*}{$\begin{array}{l}\text { 5-Distinguish quotations from } \\
\text { authors' words }\end{array}$} & Pre & 70 & 1.4286 & 2.27508 & \multirow[t]{2}{*}{24.485} & \multirow[t]{2}{*}{0.00} & \multirow[t]{2}{*}{.900} \\
\hline & post & 70 & 8.7857 & 2.15953 & & & \\
\hline \multirow{2}{*}{$\begin{array}{l}\text { 6-Locate in-text bibliographical } \\
\text { information }\end{array}$} & Pre & 70 & 1.2857 & 2.20107 & \multirow[t]{2}{*}{11.874} & \multirow[t]{2}{*}{0.00} & \multirow[t]{2}{*}{.862} \\
\hline & post & 70 & 4.6429 & 1.29699 & & & \\
\hline \multirow{2}{*}{$\begin{array}{l}\text { 7-Recognize the documentation } \\
\text { style of an educational text. }\end{array}$} & Pre & 70 & 2.2143 & 2.50155 & \multirow[t]{2}{*}{20.908} & \multirow[t]{2}{*}{0.00} & \multirow[t]{2}{*}{.976} \\
\hline & post & 70 & 8.7857 & 2.15953 & & & \\
\hline \multirow{2}{*}{$\begin{array}{l}\text { 8-Recognize entries of an } \\
\text { educational reference list. }\end{array}$} & Pre & 70 & 2.0000 & 2.46718 & \multirow[t]{2}{*}{18.214} & \multirow[t]{2}{*}{0.00} & \multirow[t]{2}{*}{.902} \\
\hline & post & 70 & 12.5714 & 5.08927 & & & \\
\hline \multirow{2}{*}{$\begin{array}{l}\text { Overall academic reading skill } \\
\text { ( Sum) }\end{array}$} & Pre & 70 & 14.2143 & 7.20486 & \multirow[t]{2}{*}{62.008} & \multirow[t]{2}{*}{0.00} & .987 \\
\hline & post & 70 & 74.6429 & 7.03621 & & & \\
\hline
\end{tabular}

The previous table (3) shows that there were statistically significant differences between the mean scores of the experimental group on the pre- and post- administrations of the academic reading test, in favor of the post-administration, since the estimated t-value for the overall reading skill was(62.008) and the estimated t-values for the eight sub-skills were (38.456), (4.971), (11.662), (22.254), (21.906), (24.485) , (11.874), (20.908), and (18.214) respectively. 


\section{Dr. Heba M. Abdullah}

Moreover, the effect size values were (.854), (.975), (.765), (.981) , (.900), (.862), (.976), (.902) for the eight academic reading sub-skills respectively and ( .987$)$ for the overall academic reading skill. These effect size values were mostly larger than the effect size value $(0.8)$. Hence, it was indicated that using the weblogs had a large effect on the experimental group students' academic reading skill on the post administration of the critical reading test results as compared with the pre-administration.

\section{Discussion}

Based on what has been mentioned above, there is evidence that the use of weblogs had a positive effect on developing academic reading skills of pre-Master students, i.e., t value was (62.008) and effect size value was (.987). This was indicated by comparing scores of the experimental group students on the pre- and post-administrations of the academic reading test. Results of the present study is consistent with results of previous studies that showed the effectiveness of using weblogs on developing some EFL learners' skills in general, and literacy, in particular (Alvarez, 2012; Alvarez and Bassa, 2013; Ananyeva, 2014; Ching-Huang et al., 2011; Cox, 2012; Davis and McGrwail, 2009; Dewi, 2013; Elbelzai, 2015; Guo, 2013; Hu and Wu, 2012, Morgan, 2015; Peterson, 2012; Stover et al., 2014; Sun, 2010; Termsinsuk, 2015; Wu, 2015).

These positive results may be related to the use of the weblog which resulted in the establishment of a supportive e-learning community. In turn, students were provided with opportunities to engage with the EAP's course reading materials and with each other. The implementation of the weblog embraced the philosophy of social constructivism where academic readings skills were developed because of the antecedent interaction and community participation, i.e., social presence. The stronger the sense of the social presence students had, the more involvement in the community they were, and the more practice was likely to take place (Kelly et al., 2016, p. 46).

In other words, students' response to the weblog posts, i.e. reading assignments, were like all social activities based on shared interests and mutual values that bounded members to one another and to the learning community itself. Hence, weblogs could be considered as the vehicle for evoking technology-mediated social environment where students' social presence could be only manifested through their involvements in focused readings discussions. 
In respect to students' responses on the weblog questionnaire, there were likely other aspects of e-learning community to be explored. Many students pointed that they liked weblogging because they began to know each other better. Besides, they found their classmates' comments beneficial. Half of the students cited that they enjoyed learning with their classmates outside the classroom. Such supportive learning environment might have resulted in diminishing physiological barriers that could hinder experience exchange among classmates, i.e. embracement. Students also noted that feedback comments in discussion threads were less threatening than feedback delivered in red pens (from instructor) or comments (from classmates) written in the margin of documents.

Students were required in the post (1) to submit a summary of their in-class reading experiences via recordings. Accordingly, they were provided opportunities for self and peer reflection. Students reported that watching their own recording was helpful in developing the ability to judge one's own understanding. In addition, students learned to build on what they had learned before. That was much emphasized by the dynamic nature of weblogging which allowed continuous contributions to take place. Hence, students were fostered to involve in a continuous process of deep reflection.

Most of the students reported that the weblog was a resourceful instructional tool which demonstrated the content materials in a wellorganized manner. Some students, who were absent in some lectures, noted that they found the work they missed in class easily via the weblog. Accordingly, they could cope with their classmates smoothly. Other students assured that weblogging encouraged them to study on time and follow a consistent schedule. Hence, students managed the process of scaffolding by themselves.

Many students noted that discussions where highly thematic and relevant. Drawing on readings assignments, together students had to negotiate meaning resulting in a shared understanding. Accordingly, a considerable amount of personal explorations was provoked and reformulated in the same discussion thread. Reading practices became active dynamic processes of meaning- making and knowledgeconstruction. In turn, academic reading skills were subjected to reinforcement. It is noteworthy that the researcher closely monitored all ongoing discussions to ensure proper reading practices and proper development of meaning-making processes.

In the weblog questionnaire, students were asked to make suggestions that might optimize the use of weblogs as EFL instructional 
tools. Most of them recommended the implementation of group-based reading projects. Due to the well-established relations among students, a common interest in group-based working was highly initiated. Other students wanted weblogs to be a venue for free writings. Such suggestion can be attributed to the well-developed social presence of students within the e-learning communities. Students showed interest in sharing and exchanging experiences with their classmates via long written texts. These suggestions may shed light on how the e-learning community provoked by the weblog was successful and beneficial.

However, some students reported that the weblog made them suffer from heavy demands of time and effort. They were continuously eager to give or receive feedbacks through regular accessing for discussions threads. In addition, they were exhausted by the process of reading, responding, editing or posting. Despite being interested, students identified time consumption as the most annoying problem in weblogging. This problem may be attributed to setting no time limits for each discussion thread.

One unanticipated challenge was that some students took the advantage of their classmates' comments, and did not make effort to demonstrate their own learning experiences. Attempting to handle this challenge, the researcher discussed with students two main criteria for successful comments namely; originality and creativity. Copied comments, i.e. plagiarized, were to be deleted by the weblog administrator, i.e., the researcher. Besides, the most two outstanding comments were to be selected and rewarded at the beginning of each lecture based on the previously mentioned criteria.

\section{Conclusion}

The main goal of the current study was to examine the effect of the use of weblogs on developing academic reading skills of pre-master students enrolled in the EAP course. Therefore, a weblog had been instructionally implemented as a complement to in-class discussion throughout the whole semester, for a period of three months. Results of the study provided an evidence on the positive effect of using the weblog on developing academic reading skills of pre-master students enrolled in the EAP course $(\mathrm{n} 2=.987)$. Students' progress can be mainly attributed to the well-established e-learning community provoked by the weblog. This study makes several noteworthy contributions to the use of weblogs in EAP contexts, in general, and reading instruction, in particular. The study was limited to the use of one type of weblogs; namely tutor. More 
research is needed to investigate the implementation of other weblogs types in relation to reading skills within EAP contexts. 


\section{Dr. Heba M. Abdullah}

\section{References}

Akbarian, I. (2010). The Relationship between Vocabulary Size and Depth for ESP/EAP Learners.System 38(3): 391-401.

Alaboudi, R. (2014). The Utility of Second Language Blogging: Student perceptions from English Writing Courses in Saudi Arabia. Ann Arbor, Southern Illinois University at Carbondale. 1568436: 66. Alexander, J. \& Bach, D. (2013). Creating Classroom Community with Reflective Blogs. International Journal of Technology, Knowledge \& Society 9(2): 17-29.

Alexander, O. (2012). Exploring Teacher Beliefs in Teaching EAP at Low Proficiency Levels. Journal of English for Academic Purposes 11(2): 99-111.

Aljumah, F. (2012). Saudi Learner Perceptions and Attitudes Towards the Use of Blogs in Teaching English Writing Course for EFL Majors at Qassim University. English Language Teaching 5(1): $100-116$.

Álvarez, G. (2012). New Technologies in the University Context: The Use of Blogs for Developing Students' Reading and Writing Skills. International Journal of Educational Technology in Higher Education 9(2): 185-199.

Álvarez, G. \& Bassa, L. (2013). ICTs and Collaborative Learning: A Case Study of a Class Blog for Improving the Writing Skills of Pre-University Students. International Journal of Educational Technology in Higher Education 10(2): 254-268.

Asoodar, M. et al. (2014). Learner Reflections in Virtual vs. Blended

EAP Classes. Computers in Human Behavior 41: 533-543.

Ananyeva, M. (2014). Blogfolios and their Role in the Development of Research Projects in an Advanced Academic Literacy Class for ESL Students." TechTrends 58(5): 22-26.

Ayers, M. (2011). Toward Authentic Audiences: Blogging in a High School English Classroom. Ann Arbor, The University of Iowa. 3494143: 228.

Bankowski, E. (2010). "Developing Skills for Effective Academic Presentations in EAP." International Journal of Teaching and Learning in Higher Education 22(2): 187-196.

Bartholomew, M. et al. (2012). A Community of Voices: Educational Blog Management Strategies and Tools. TechTrends 56(4): 1925.

Cai, L. (2013). Students' Perceptions of Academic Writing: A Needs Analysis of EAP in China. Language Education in Asia 4(1): 522. 
Campion, G. (2016). The Learning Never Ends: Exploring Teachers' Views on the Transition from General English to EAP." Journal of English for Academic Purposes 23: 59-70.

Ching-Huang, W. et al. (2011). A University e-Campus Blog for Paragraph Writing in English Grammar Courses. International Journal of Technology, Knowledge \& Society 7(3): 87-99.

Coppens, X., et al. (2013). Using Blogs: Authentic Material and Ranking Quality for SLA. The EUROCALL Review 21(1): 20-34.

Cox, T. (2012). Promoting Blogging to Improve Interpersonal and Presentational Writing Skills while Increasing Cultural Competency in an English Language Learning Setting. Ann Arbor, University of Arkansas at Little Rock. 1511151: 211.

Davis, A. \& McGrail, E. (2009). Proof-Revising with Podcasting: Keeping Readers in Mind as Students Listen to and Rethink Their Writing. Reading Teacher 62(6): 522-529.

Dewi, W. (2013). Weblogs: An Alternative Solution in Improving High School Students' Writing Skill. Retrieved from https://eric.ed.gov/?id=ED541875.

Dooey, P. (2010). Students' Perspectives of an EAP Pathway Program. Journal of English for Academic Purposes 9(3): 184-197.

Durrant, P. (2009). Investigating the Viability of a Collocation List For students of English for Academic Purposes. English for Specific Purposes 28(3): 157-169.

Elbelazi, S. (2015). The Use of Technology in Second Language Literacy: Does it work? Arab World English Journal: 116-123.

Esnawy, S. (2016). EFL/EAP Reading and Research Essay Writing Using Jigsaw. Procedia - Social and Behavioral Sciences 232: 98-101.

Featro, S. \& DiGregorio , D. (2016). Blogging as an Instructional Tool in the ESL Classroom. TESL-EJ 20(1).

Glicker, E. (2010). The Student Writer as Blogger: A Longitudinal Case Study of a Blogger's Critical Narrative Events. Ann Arbor, Indiana University of Pennsylvania. 3403188: 275.

Goldstein, A. (2009). Blogging Evolution. Evolution: Education and Outreach 2(3): 548-559.

Green, J. (2015). Teaching for Transfer in EAP: Hugging and Bridging Revisited. English for Specific Purposes 37: 1-12.

Guo, L. (2012). Chinese EAL Learners' Perceptions of Academic Writing Practices in a Canadian University. Ann Arbor, University of Manitoba (Canada). MS22426: 257. 
Guo, Y. (2013). The Class Blog: Chinese EFL Non-English Major College Students' Online Writing Experiences. Ann Arbor, University of Missouri - Columbia. 10180814: 312.

Hajizadeh, R. (2011). A Weblog as a Tool for Reflection for English Language Learners, Retrieved from https://eric.ed.gov/?id=ED522676.

Houston, M. (2014). Writing Stories Across Languages: The Exploration of Students' Books Construction in an EAP Writing Classroom. Ann Arbor, Indiana University of Pennsylvania. 3665926: 273.

Hu, H. \& Wu , H. (2012). Writing-Research on Vocational College English-Teaching Based on Web-Blog. Education and Educational Technology. Springer Berlin Heidelberg.

Huang, J. et al. (2010). Teacher Perceptions of ESOL Students' Greatest Challenges in Academic English Skills: A K-12 Perspective. International Journal of Applied Educational Studies 8(1): 6880.

Hung, S. (2011). Pedagogical Applications of Vlogs: An Investigation into ESP Learners' Perceptions. British Journal of Educational Technology 42(5): 736-746.

Hutchison, A. \& Wang, W. (2012). Blogging within a Social Networking Site as a Form of Literature Response in a Teacher Education Course. Educational Media International 49(4): 263275.

Irmawati, N. (2012). Communicative Approach: An Alternative Method Used in Improving Students' Academic Reading Achievement. English Language Teaching 5(7): 90-101.

Jayne, V. (2013). Blogging to Support Learning Community and Writing Goals in a Mixed Composition Classroom. Ann Arbor, Purdue University. 3591290: 184.

Johnson, C. (2012). Directed Blogging with Community College ESL Students: Its Effects on Awareness of Language Acquisition Processes. Ann Arbor, Pepperdine University. 3518863: 121.

Johnson, D. (2010). Teaching With Authors' Blogs: Connections, Collaboration, Creativity. Journal of Adolescent \& Adult Literacy 54(3): 172-180.

Kelsey, T. (2010). Designing and Sharing Your Blog. Berkeley press Khany, R. \& Tarlani-Aliabadi, H. (2016). Studying Power Relations in an Academic Setting: Teachers' and Students' Perceptions of EAP Classes in Iran. Journal of English for Academic Purposes 21: 72-85. 
Kitchakarn, O. (2012). Using Blogs to Improve Students' Summary Writing Abilities. Turkish Online Journal of Distance Education 13(4): 209-219.

Kitchakarn, O. (2014). Developing Writing Abilities of EFL Students through Blogging. Turkish Online Journal of Distance Education 15(4): 34-47.

Klimova, F. (2015). Designing an EAP Course. Procedia - Social and Behavioral Sciences 191: 634-638.

Krishnan, N. (2010). Blog Reading a Motivation Model. Ann Arbor, MICA (Mudra Institute of Communications, Ahmedabad) . 1528441: 58 .

Kuteeva, M. (2011). Wikis and Academic Writing: Changing the Writer-Reader Relationship. English for Specific Purposes 30(1): 44-57.

Kuzborska, I. (2011). Teachers' Decision-Making Processes when Designing EAP Reading Materials in a Lithuanian University Setting. Journal of English for Academic Purposes 10(4): 223237.

Lacina, J. \& Griffith, R. (2012). Blogging as a Means of Crafting Writing. Reading Teacher 66(4): 316-320.

Lerma, T. (2013). Using Blogs as a Tool to Improve L2 Vocabulary Acquisition. Ann Arbor, The University of Texas at San Antonio. 1545311: 78.

Li, C. \& Ruan, Z. (2015). Changes in Beliefs about Language Learning among Chinese EAP Learners in an EMI Context in Mainland China: A Socio-Cultural Perspective. System 55: 43-52.

Lin, H. (2014). Effects of Classroom Blogging on ESL Student Writers: An Empirical Reassessment. The Asia-Pacific Education Researcher 23(3): 577-590.

Lin, H. et al. (2011). The Unrealistic Claims for the Effects of Classroom Blogging on English as a Second Language, Students' Writing Performance. British Journal of Educational Technology 42(6): E148-E151.

Lou, J. (2010). EFL University Students' Reading of Academic English Texts: Three Case Studies of Metacognition in Taiwan. Ann Arbor, The Ohio State University. 3424659: 225.

Makhadmeh, M. (2011). A Survey of the Motivations for Reading Blogs by Jordanian University Media and Journalism Students. Ann Arbor, Arkansas State University. 1496820: 88. 


\section{Dr. Heba M. Abdullah}

Mansourizadeh, K. \& Ahmad, K. (2011). Citation practices among NonNative Expert and Novice Scientific Writers. Journal of English for Academic Purposes 10(3): 152-161.

McCollum, R. (2011). Writing from Sources and Learners of English for Academic Purposes: Insights from the Perspectives of the Applied Linguistics Researcher, the Program Administrator, and the Classroom Teacher. Ann Arbor, Brigham Young University. 3502468: 107.

McGrath, L. et al. (2016). Reading EAP: Investigating High Proficiency L2 University Students' Strategy Use through Reading Blogs. Journal of English for Academic Purposes 22: 152-164.

Huei, L. et al. (2013). Blog-Assisted Learning in the ESL Writing Classroom: A Phenomenological Analysis. Journal of Educational Technology \& Society 16(3): 130-139.

Morgan, H. (2015). Creating A Class Blog: A Strategy That Can Promote Collaboration, Motivation, And Improvement in Literacy. Reading Improvement 52(1): 27-31.

Naidu, B. et al. (2013). Reading Strategy: Tackling Reading through Topic and Main Ideas. English Language Teaching 6(11): 6064.

Neculai, C. (2016). Power and Meaning Making in an EAP Classroom: Engaging with the Everyday. Journal of English for Academic Purposes 21: 137-140.

Nergis, A. (2013). Exploring the Factors that Affect Reading Comprehension of EAP Learners. Journal of English for Academic Purposes 12(1): 1-9.

Park, S. (2013). The Potential of Web 2.0 Tools to Promote Reading Engagement in a General Education Course. TechTrends 57(2): 46-53.

Peterson, J. (2009). Weblog Writing and Post-Process Eco composition Theory in Secondary English Instruction. Ann Arbor, Tennessee State University. 1469274: 84.

Peterson, M. (2012). Connectivity and Collaboration: The Use of Blogs in First-Year Composition. Ann Arbor, The University of Alabama at Birmingham. 1512848: 75.

Pluck, G. (2013). Teaching Psychology through English: Incidental Improvement in Academic Reading Comprehension. Journal of Educational Sciences \& Psychology 3(1): 38-42.

Quadir, B. \&. Chen, N (2015). The Effects of Reading and Writing Habits on Learning Performance in a Blog Learning 
Environment. The Asia-Pacific Education Researcher 24(4): 635-644.

Ro, E. (2016). Exploring Teachers' Practices and Students' Perceptions of the Extensive Reading Approach in EAP Reading Classes. Journal of English for Academic Purposes 22: 32-41.

Ruggiero, M. (2016). Literature blogs: How does the Use of Blogs Affect Students' Perceptions of Literature. Ann Arbor, The William Paterson University of New Jersey. 10127829: 58.

Sadikin, I. \& Saleh, M. (2016). Weblog-Based Learning in an EFL Young Learners' Context: Students' Perspective. Arab World English Journal(3): 58-78.

Sandlin, J. (2013). The Blog Dress Rehearsal: College Identity, Anxiety and Compatibility. Journal of College Admission (221): 38-45.

Schmitt, D.\& Hamp-Lyons , L. (2015). The Need for EAP Teacher Knowledge in Assessment. Journal of English for Academic Purposes 18: 3-8.

Seviour, M. (2015). Assessing Academic Writing on a Pre-Sessional EAP Course: Designing Assessment Which Supports Learning. Journal of English for Academic Purposes 18: 84-89.

Shing, S. \& Sim, T. (2011). EAP Needs Analysis in Higher Education: Significance and Future Direction. English for Specific Purposes World 33: 1-11.

Smith, G. (2009). Voices from the Field: Obtaining, Processing, and Constructing English: Blogging in the ESL Classroom. Journal of Media Literacy Education 1(1): 75-80.

Afshar, H \& Movassagh , H. (2016). EAP Education in Iran: Where Does the Problem Lie? Where Are We Heading? Journal of English for Academic Purposes 22: 132-151.

Spies, T. (2011). Academic Language Proficiency Development and its Impact on Reading Comprehension: Within and Across Languages. Ann Arbor, Texas A\&M University. 3471240: 116.

Storch, N. \& Tapper, J. (2009). The Impact of an EAP Course on Postgraduate Writing. Journal of English for Academic Purposes 8(3): 207-223.

Stover, K. et al. (2014). Experience Is the Best Tool for Teachers: Blogging to Provide Preservice Educators with Authentic Teaching Opportunities. Journal of Language and Literacy Education 10(2): 99-117.

Suh, Y. (2011). Exploring Reading Strategy Use in English Academic Reading Practices in an EFL Context: Case studies of Four 


\section{Dr. Heba M. Abdullah}

Korean College Students. Ann Arbor, Indiana University. 3449576: 302.

Sun, Y.(2010). Extensive Writing in Foreign-Language Classrooms: A Blogging Approach. Innovations in Education \& Teaching International 47(3): 327-339.

Suryani, I. et al. (2012). Using Weblog in Learning English and Encouraging Adaptation among International Students in Perlis. Higher Education Studies 2(1): 27-31.

Taboada, A. \& Buehl, M. (2012). Teachers' Conceptions of Reading Comprehension and Motivation to Read. Teachers and Teaching 18(1): 101-122.

Termsinsuk, S. (2015). Development of a Blended Instructional Model via Weblog to Enhance English Summary Writing Ability of Thai Undergraduate Students. IAFOR Journal of Education. Doi. 10.22492

Terraschke, A. \& Wahid , R. (2011). The Impact of EAP Study on the Academic Experiences of International Postgraduate Students in Australia. Journal of English for Academic Purposes 10(3): 173-182.

Veenendaal, N. et al. (2015). What Oral Text Reading Fluency Can Reveal about Reading Comprehension. Journal of Research in Reading 38(3): 213-225.

Wan, J.\& Tan, B. (2011). Weblogs for English Language Learning: Students' Perceptions. Turkish Online Journal of Distance Education 12(4): 115-132.

Wan, W. et al. (2012). The Application of Network Blog in College English Teaching. Proceedings of the International Conference on Green Communications and Networks (GCN 2011). Y. Yang and M. Ma. Dordrecht, Springer Netherlands: 307-314.

Ward, J. (2009). EAP Reading and Lexis for Thai Engineering Undergraduates. Journal of English for Academic Purposes 8(4): 294-301.

Wette, R. (2014). Teachers' Practices in EAP Writing Instruction: Use of Models and Modeling. System 42: 60-69.

Wilson, K. (2016). Critical Reading, Critical Thinking: Delicate Scaffolding in English for Academic Purposes (EAP). Thinking Skills and Creativity 22: 256-265.

Wingate, U. (2012). Using Academic Literacies and Genre-based Models for Academic Writing Instruction: A Literacy Journey. Journal of English for Academic Purposes 11(1): 26-37.

Wu, H.(2015). The Effects of Blog-supported Collaborative Writing on Writing Performance, Writing Anxiety and Perceptions of EFL 
College Students in Taiwan. Ann Arbor, University of South Florida. 3700402: 302.

Wu, H. \& Wu, P. (2011). Learners' Perceptions on the Use of Blogs for EFL Learning. Retrieved from https://eric.ed.gov/?id=ED524902.

Yigitoglu, N. (2016). Power and Meaning Making in an EAP Classroom: Engaging with the Everyday. English for Specific Purposes 42: 124-125.

Zawilinski, L. (2009). HOT Blogging: A Framework for Blogging to Promote Higher Order Thinking. Reading Teacher 62(8): 650661.

Zhou, A. (2009). "What Adult ESL Learners Say about Improving Grammar and Vocabulary in their Writing for Academic Purposes. Language Awareness 18(1): 31-46.

Kelly, N. et al. (2016). Presence, Identity, and Learning in Online Learning Communities. London, Palgrave Macmillan. 